\title{
DO REGULATION, MAQASID SHARIAH AND INSTITUTIONAL PARAMETER IMPROVE ISLAMIC BANK EFFICIENCY?
}

\author{
Wan Hakimah Wan Ibrahim ${ }^{1}$ and Abdul Ghafar Ismail ${ }^{2}$ \\ Universiti Sultan Zainal Abidin, Malaysia,wanhakimah84@gmail.com \\ Johor Islamic Studies College, Malaysia, agibab62@gmail.com
}

\begin{abstract}
We use a new dataset on Islamic banks to link regulation and bank efficiency. Specifically, we examine how bank efficiency is influenced by: (i) bank regulation, (ii) institutional variables, (iii) economic freedom, and (iv) Shariah law parameters. Our hypothesis attempts to prove that better regulation will produce a higher level of efficiency. We will also try to prove that the Shariah law parameter will promote better efficiency among Islamic banks. Data Envelopment Analysis (DEA) is used to measure efficiency, while the panel data method is used to analyse the data. Specifically, our results suggest that a significant relationship exists between bank efficiency and greater restrictions on Islamic bank activities. The results also show that regulatory quality has a positive and significant impact on bank efficiency. The negative coefficient of the economic freedom indicates that Islamic banks have a greater ability to enter into the banking industry and obtain an easy licence, create products and services, and close the business. All would dampen bank efficiency. Overall, our findings support the argument that regulation should be adapted to the risk and size level of the Islamic banks that are being regulated.
\end{abstract}

Keywords: Bank regulation, Efficiency, Panel data, DEA, Maqasid shariah index. JEL Classification : C23; G18; G21; G28; L51.

Article history:

Received : October 24, 2019

Revised : December 5, 2019

Accepted : January 8, 2020

Available online : February 28, 2020

https://doi.org/10.21098/jimf.v6i1.1195 


\section{INTRODUCTION}

\subsection{Background}

In the $21^{\text {st }}$ century, the structure of regulation has been accompanied in parallel with stringent rules, particularly within the regulation of capital adequacy. As a result, a number of researchers have highlighted the role of regulation in supporting the development of banking. In effect, this has led to economic growth and an improvement in economic crises (Ajakaiye \& Tarp, 2012; Hassan \& Dridi, 2010; Hassan, Sanchez, \& Yu, 2011; Massally \& Duff, 2018; Murinde, 2012; Yilmzazkuday, 2011). This research highlights the 'specialness' of banks in the economy. Therefore, there is a need to maintain bank stability, and as a result, the banking industry is heavily regulated and supervised. International agencies such as the International Monetary Fund, World Bank, the Bank for International Settlements, and the Islamic Financial Services Board have created many checklists on best practices in running a bank and they encourage all countries to use them (Chortareas, Girardone, \& Ventouri, 2012). All countries should thus be aiming to use these practices to provide timely, effective and cohesive responses to financial distress during a crisis.

However, as argued by Zhang, Wang, and Qu (2012), and Ibrahim and Ismail (2015), the appropriate protection of stakeholders could also be secured if regulatory frameworks are well developed. In addition, this framework is critical for maintaining confidence at an institutional level and within the financial system as a whole. It shows that the law origin supports relevancy and effectiveness in order to achieve financial stability and support inclusive growth in the financial system and the economy, as well as providing suitable security for stakeholders. The regulatory framework is also introduced to guarantee that any new regulation is more robust against unpredicted market condition changes, at the same time as providing banking institutions with enough flexibility to operate in a manner that is consistent with their own strategic objectives, business models, size and risk profile.

Nevertheless, the impact of changes in regulations does not always reflect accuracy. This was proven by Barth et al. (2004), (2006), (2008), and (2013), who present research with contradictory expectations about the influence of regulation policy on bank performance. In addition to that, since the new regulatory framework of Islamic banking has been implemented in several countries, the flow of impact of regulation policy on Islamic banking has differed because of the existence of a multi-contract scheme (Ibrahim \& Ismail, 2015; Ismail \& Tohirin, 2010).

This study attempts to clarify issues that exist in the Islamic banking industry where, as it is known, Islamic banking activities are based on Shariah law in order to achieve Maqasid Shariah. However, these Islamic banking rules are governed by civil law or under the jurisdiction of the civil court. As explained by Hasan and Dridi (2010), Islamic banking laws have been enforced under the rule of civil law. This is because, according to legal facts, Islamic banking is considered a 'financial' item under the Federal Constitution. This situation has contributed to the issue of arbitrage. Furthermore, the existence of arbitrage in regulation will affect the operations and management of a banking and financial institution in terms of both liquidity and lending. This is due to the fact that each rule and regulation 
implemented through BNM is based on the specification of conventional banking regulations such as the application of regulatory capital standards under Basel III, which is applicable to Islamic banking (Monitoring and Supervision Framework, 2013 ).

Moreover, Barth et al. (2013) highlight the fact that the current studies are unclear in explaining the prediction of the impact of bank regulation due to two conflicting viewpoints. First, in order to promote their efficiencies, and at the same time avoid market failures, the public interest view is considered for regulating banks. Second, the private interest view outlines that regulation is often used to promote the interests of some particular party rather than the general public. This results in banks working on political matters or other regulations; therefore, they do not play an active role in improving efficiency. Therefore, the impact of regulation on efficiency is unclear for these two opposing views. Some of the empirical studies are reported in Barth et al. (2008), Chortareas, Girardone, and Ventouri (2012), and Barth et al. (2013). Hence, additional empirical studies, such as our study, would help to enrich the literature.

On the other hand, there are only a few studies that examine the impact of bank regulation on the level of efficiency. One such study is Alam (2013), who conducted research on whether bank regulation, supervision and monitoring improve technical efficiency and risk-taking behaviour among Islamic banks. Sassi (2013) examined the relationship between the regulatory and institutional indicators and the technical efficiency of commercial banks in MENA countries. The findings of these studies have motivated us to perform a similar assessment on the changes of bank regulation. Furthermore, we have been led to look at contract enforcement with bank efficiency on full-fledged Islamic banks since there are arguments on economic theory and its role in defining the impact of regulatory policies on bank efficiency (Barth et al., 2004, 2008, 2013).

In addition, a lot of previous studies have focused on the progress of Islamic banks, particularly on bank performance and efficiency. However, most have applied the 'conventional' measurement without considering a significantly different method that regulates the Islamic banking industry. Therefore, the studies completed by Mohammed et al. (2015), Antonio et al. (2012), Jazil and Syahruddin (2013), and Ngalim et al. (2015) proposed a measurement that would not only measure the banks' state in achieving the objective of shariah, but also their effects on the development of economics, particularly Islamic financial institutions.

\subsection{Objective}

The aim of this paper is to construct a model to analyse and calculate banks' efficiency, and at the same time, analyse the impact of bank regulation changes. This will be executed by combining the advantages of existing models, procedures and methods with the implementation of Islamic law.

This paper contributes to the present literatures in three aspects; first, to produce a new result based on the new data set; second, to look at the impact of the shariah law parameter on bank efficiency. The assessment of the impact of these variables will improve our understanding of the business cycle and the law origin on the efficiency of Islamic banks. 
The paper is organised as follows. Section 2 describes the issues of regulation, contract enforcement and efficiency in the banking sector. Section 3 describes the model and the sample of data. Section 4 discusses the empirical results, and lastly, section 5 presents conclusions.

\section{LITERATURE REVIEW}

\subsection{Banking Regulation, Maqasid Shariah Index and Bank Efficiency}

In financial institutions, efficiency is often linked to banks. A wide range of studies within this field have been conducted, including:

(i) Analysis of bank efficiency such as Ayadi et al. (2013), Beck et al. (2012), AlJarhi (2009), Hughes and Mester (2008), and Battese and Coelli (1995).

(ii) Cost and profit efficiency by Kamarudin and Yahya (2013), Girardone et al. (2009), Al-Delaimi and Batall (2006), Ahmad Mokhtar et al. (2007), and Fries and Taci (2004).

(iii) Bank efficiency and crisis by Ftiti et al. (2013), Reverchuk et al. (2013), Barra et al. (2013), Forughi and Zoysa (2012), and Sufian (2009).

Recently, with the increasing challenges faced by financial institutions, the banking act is being reviewed and redefined. This is to facilitate financial policy makers to control and oversee the protection of investors and customers, as well as ensuring the stability and efficiency of the banking institution system. Issues related to this rule are often debated by many researchers. For example, Barth et al. (2008) said that the outbreak of the East Asian Financial Crisis in the late 1990s had impacted many countries. After the crisis, developing countries and Asian countries made significant changes to the regulatory and supervisory framework of banks through financial systems. Each change was made in accordance with Basel guidelines, which are strengthening capital requirements and enhancing supervisory bodies. The study formulated a survey consisting of 12 divisions as a proxy of regulations, namely: (1) entering the banking industry; (2) ownership; (3) capital; (4) activities; (5) external audit requirements; (6) internal management/ organisational requirements; (7) liquidity and diversification requirements; (8) deposit protection schemes; (9) allocation requirements; (10) information and accounting disclosure requirements; (11) institutional discipline/issues; and (12) supervision. The findings of the study show that the implementation of these measures has led to improvements in the banking system such as efficiency, stability and corruption management.

The impact of regulation and supervision on bank efficiency is increasing and it has been a hot topic among researchers. For example, Barth et al. (2013) studied whether bank regulation, supervision and monitoring will promote or prevent banks from operating efficiently. Based on an unbalanced panel analysis of observations of 4,050 banks in 72 countries from 1999 to 2007, they found that when regulations on bank activity were tightened, there was a negative impact on bank efficiency. On the other hand, tightening capital controls would positively impact bank efficiency. This study differs from Barth et al. (2013), whereby the index of Maqasid Shariah was constructed as an Islamic banking variable.

Meanwhile, a study from Sassi (2013) attempted to analyse the correlation between the institutional rules, along with the indicators, and the technical 
efficiency of commercial banks in five MENA countries from 2003 to 2011. To measure bank efficiency, researchers have calculated efficiency using nonparametric methods, namely, Data Envelopment Analysis (DEA). Intermediate methods are used to determine input and output variables. In reference to Barth et al. (2001, 2006), the regulatory variables are activity restrictions, capital requirements, official supervisory powers and market monitoring. Furthermore, the study used Tobit's estimation to study the specific effects of bank carriers, control indicators, regulations and economic freedom indexes. The empirical results show that strong restrictions will reduce bank efficiency.

Apart from that, Chortareas et al. (2012) analysed the dynamic nature of bank regulation and supervisory policies related to Basel II's three pillars and various aspects of bank cost-efficiency and performance using European Union (EU) commercial bank samples from the period 2000 to 2006. This study used frontier analysis and traditional accounting ratios to calculate efficiency. In addition, the quasi-likelihood estimation approach is used to produce more robust and efficient results compared to Ordinary Least Squares (OLS) and Tobit regression for models with dependent variables that vary for each estimation model. The results show that the supervision and control of interventions such as authorising capital restriction, strengthening formal supervisory powers, monitoring the private sector and restricting bank activities may hinder banks' operational efficiency. The evidence also shows that banks from countries with a more open, competitive and democratic political system are more likely to benefit from higher levels of operational efficiency.

Demirguc-Kunt et al. (2004) studied the effect of bank regulation, market structure and domestic institutions on intermediary costs and calculated the results based on account rates (net interest margin and overhead costs). Information on bank regulation obtained from Barth et al. (2001b; 2003) is a database for 1,400 banks operating in 72 countries from 1995 to 1999. The study used net interest margins as a dependent variable to measure the level of efficiency and performance of banking. The results show that the stringent regulation of banking services and activities increases the financial intermediary costs. This is in line with the view that allowing banks to engage in a variety of activities will make the banking institutions better and more stable.

Moreover, Barth et al. (2004) studied the relationship between banking regulation and monitoring, as well as the development, performance and stability of banking (efficiency is an external variable). In particular, they created and carried out surveys funded by the World Bank to collect information on banking regulations and monitoring used by 107 countries. The results show that there is a very weak economic relationship between activity restriction and bank efficiency; indeed, Barth et al. (2004) argued that barriers to foreign bank participation will increase bank volatility and reduce the efficiency of the banking industry.

However, from other perspectives, there are several studies that determine this relationship differently. From some viewpoints, there is a positive relationship between regulation and bank efficiency. Positive findings indicate that higher banking regulations will improve bank efficiency. For example, Nafis (2013) studied the relationship between bank regulation, supervision and monitoring with the aim of determining whether these variables enhance or reduce the 
efficiency and nature of technical risk taking for Islamic banks worldwide. Using technical efficiency scores, the study was conducted for the period 2006 to 2010. Thereafter, the seemingly unrelated regression approach (SUR) was used, and the results concluded that the strict regulation and monitoring of banking operations and higher supervisory authority of officials would increase the technical efficiency of Islamic banks. This study differs from Nafis' (2013) study, not only from the Maqasid Shariah parameters used in the regression model, but also from the relationship measurement standpoint where this study uses a panel model approach to investigate the relationship between technical efficiency and the variables used.

Similarly, Pasiouras et al. (2008) evaluated the effect of a supervisory and monitoring framework on bank efficiency using stochastic frontier analysis (SFA). The dataset, which consisted of 2,853 observations, was selected from 615 commercial banks operating in 74 countries for the period 2000 to 2004 . The study uses the three pillars of Basel II, which are the cost and profitability of banks, the ability to control other countries' specific features, and restrictions on banking activities, as a means of studying the effects of regulations. Their findings suggest that incentive regulation acts as an influence on market discipline and higher supervisory power on the authority, thereby enhancing both cost-efficiency and profitability.

\subsection{Background Theory}

Based on the theoretical underpinnings, most of the statements on the relationship between banking regulation and banking efficiency are diverse (Haque \& Brown, 2016). According to Allen and Carletti (2013), the basic theoretical framework of the banking regulations and the agreement on what to do is still not sufficient to formulate and reform the rules. To explain the relationship between banking regulation and banking efficiency, Barth et al. (2013) provided two views. The first concept is 'public interest', in which the government acts as an agent to protect the interests of the public through the regulatory process of banking activities, which indirectly raises the level of bank efficiency. This in turn addresses the problem of market failure. Subsequently, the second view of 'individual interests' describes specific banks formulating rules or enforcing regulations to maximise the interests of certain groups, which indirectly reduces the banks' efficiency. Therefore, a study of the regulation of Islamic banking on efficiency level is generally needed to change the structure of conventional rules to Islamic rules in order to achieve Maqasid Shariah. Recently, the study of the relationship between the performance of Islamic banking institutions and Maqasid Shariah has gained popularity among many researchers such as Ngalim and Ismail (2014) , Jazil and Syahruddin (2013), Antonio et al. (2012), and Mohammed et al. (2008). The continuation of this study is to assess the activities and operations of bank efficiency with the aim of achieving the main objective of Maqasid Shariah and its impact on the level of technical efficiency within Islamic banking. 


\subsubsection{Regulation}

Generally, activity restriction has two effects - either positive or negative-on the level of efficiency (Haque \& Brown, 2016). From the view of public interest, activity restriction can reduce the risk of moral hazard and prevent banks from becoming larger and more complex, which requires oversight and discipline (Barth et al., 2013; Laeven \& Levine, 2009). This may indirectly increase banks' efficiency. On a different note, the private interest view explains that increased activity restrictions will reduce economies of scale and the scope of information processing, as well as provide a variety of services to customers (Haque \& Brown, 2016). Furthermore, according to Agoraki et al. (2011), activity restrictions can reduce the likelihood of risk diversification and the involvement of non-interest income, which may indirectly reduce the overall bank efficiency. Therefore, the empirical results show that the relationship of activity restrictions to efficiency is varied. Nonetheless, Barth et al. (2013) and Chortareas et al. (2012) asserted that tighter restrictions on bank activity may have a negative impact on bank efficiency. Pasiouras et al. (2009 ) also explained the opposing relationship between activity restriction and efficiency. According to them, activity restriction can have a positive impact on bank efficiency as it reduces the prospect of diversification and non-interest income activities where the scope of activities can be implemented more efficiently. Therefore, this study developed the following hypothesis:

Hypothesis 1: Activity Restrictions (ARCs) are positively related to bank efficiency.

\subsubsection{Maqasid Shariah Index}

The concept of the Maqasid Shariah index is aimed at promoting the value of welfare and benefits (Jalb al-Masalih) and overcoming misery (Dar'al-Mafasid) (Antonio et al., 2012; Jauziyah, 1973; Yubi, 1998). According to other views, Maqasid Shariah is divided into three categories, namely tahdzib al-fard (education for individuals), iqamah al-adl (justice), and maslahah (benefits/welfare). In general, this index was developed as a measurement to assess the performance of Islamic banking (Antonio et al., 2012).

Previous studies such as Antonio et al. (2012) used the Maqasid Index approach to study the performance of the Islamic banking industry. A study entitled 'An Analysis of Islamic Banking Performance: Maqasid Index Implementation in Indonesia and Jordan' uses four Islamic banking samples consisting of two Islamic banks, respectively, in Indonesia (Islamic Shariah Bank and Indonesia Muamalat Bank) and Jordan (Jordan Islamic Bank and Islamic International Arab Bank of Jordan) from 2008 to 2010. Due to data constraints, this study only formed eight Maqasid Shariah ratios compared to the ten recommended ratios representing the three Maqasid Shariah variables. Using the Maqasid Index approach through the Simple Additive Weighting method (SAW), the results show that the Maqasid Index for Indonesia's Islamic banking industry is higher than Jordan.

Another study entitled 'The Performance Measures of Islamic Banking Based on the Maqashid Framework' was conducted by Mohammed et al. (2008). In this study, the concept of the Maqasid Index was developed using the SAW approach. A total of six Islamic banks were used as the sample: Bank Muamalat Malaysia, Islamic Bank Bangladesh, BSM (Islamic Bank of Indonesia), Bahrain Islamic Bank, 
IIABJ (Islamic International Arab Bank of Jordan), and Islamic Bank of Sudan for the study period 2000 to 2005 . The variables used were in reference to the Maqasid Shariah theory described by Abu Zahrah and consisted of al-Fard, Iqamah Al-Adl, and Maslahah. The variables were minimised using the concept of circulation, resulting in ten ratios that were indicative of performance. In the study, only seven out of the ten ratios were used. The results showed that the seven ratios used did not reflect the high performance of each Islamic bank in the sample. However, IIABJ Jordan was found to ranked the highest followed by BSM Indonesia, Bank Islam Bahrain, Bank Islam Bangladesh, Bank Muamalat Malaysia, and finally, Islamic Bank Sudan. Therefore, in compliance with the prescribed Maqasid Shariah, Islamic banks should re-evaluate their goals and objectives, especially in their daily business activities.

Besides that, Ibrahim et al. (2004) suggested an alternative assessment of Islamic banking performance. They used a sample comprising two Islamic banks, namely Bank Islam Malaysia Berhad (BIMB) and Bahrain Islamic Bank (BIB). In assessing the performance of Islamic banking, an index of Islamic disclosures was developed that consisted of several indicators such as shariah compliance, corporate governance, and the social environment. These indicators were represented by seven criteria, namely profit-sharing ratio, charity performance ratio, fair distribution ratio, directors' welfare ratio, Islamic investment vs. nonIslamic investment, Islamic income vs non-Islamic income, and the AAOIFI index. The results show that Islamic banking performance is in a situation that requires special attention as some of the information and data had not yet been fully disclosed and presented to stakeholders. Based on the sample used, BIMB did not provide complete information as compared to BIB.

Furthermore, Kuppusamy et al. (2010) conducted a study with the research title "Measurement of Islamic Banks Performance Using a Shariah Conformity and Profitability Model". This study used four banks from Malaysia, Bahrain, Kuwait and Jordan for the period 2001 to 2004. The Shariah Compliance and Profitability model (SCnP) was shaped by a combination of conventional and Shariah-compliant financial performance indicators. The Shariah-compliant indicators included Islamic investment ratios, Islamic income ratios and profitsharing ratios. The profitability of each bank was measured by the ratios of return on assets (ROA), return on equity (ROE) and profit-sharing ratio. The results showed that the majority of Islamic banks can achieve high profitability and good Shariah compliance, despite only one bank having a profit and a low level of Shariah compliance.

This indicates that Islamic bank performance was undertaken in conjunction with Shariah-compliant indicators by each of the banks involved. This will indirectly affect the efficiency and effectiveness of the Islamic banking system. As explained by Mangkuprawira (2009), superior performance is characterised by efficient and effective work. Whereas, according to Antonio et al. (2012), nonfinancial information used as a performance benchmark enhances confidence in the quality control management process. The performance measurement covers four aspects, namely financial perspective, customer satisfaction, internal process efficiency, and learning and growth. 
The positive relationship between the Shariah Maqasid index and its efficiency indirectly meets the concept of public interest, whereby any activity that is undertaken in accordance with Shariah Maqasid principles will enhance the efficiency of Islamic banks.

Hypothesis 2: The Maqasid Shariah Index is positively related to bank efficiency.

\subsubsection{Institutional Aspects}

Institutional control is often associated with the governance of government sectors. Improving the quality of governance can indirectly increase the size of the financial sector and efficiency of a country. According to Kamarudin et al. (2016), Cooray (2011), Beltratti and Stulz (2009), Kuipers et al. (2009), and Lensink et al. (2008), the elements under institutional control are important in aiding the improvement of industry efficiency. The quality control data of institutions by Kaufmann et al. (2007) classified institutional control into six elements, particularly: (i) Voice and Accountability (VA); (ii) Political Stability (PS); (iii) Government Effectiveness (GE); (iv) Quality Supervision (RQ); (v) Legal Regulation (RL); and (vi) Corruption Control (CC). For the purpose of this study, only two elements were considered to assess the influence of institutional controls on competencies, namely RQ and RL. The RQ and RL elements were selected because, apart from their impact on efficiency, RQ and RL were also linked to the ability and quality of the rules that are formed in achieving Maqasid Shariah.

According to Kamarudin et al. (2016) both RQ and RL elements influence the efficiency of the banking industry. A study entitled "Does country governance foster revenue efficiency of Islamic and conventional banks in GCC countries?" investigated the impact of governance on the efficiency of revenue for Islamic and conventional banking. A total of 74 banks made up of 47 conventional banks and 27 Islamic banks for the period 2007 to 2011 were selected as the sample. The DEA approach was used to obtain three different measurements of efficiency, namely revenue efficiency, cost-efficiency and profit efficiency. Non-parametric t-tests such as the Mann-Whitey (Wilcoxon) and Kruskall-Wallis tests were used to detect differences in Islamic and conventional banking efficiency. Additionally, secondary analyses such as OLS and Generalised Method of Moments (GMM) were performed to analyse the determinants and effects of governance on outcome efficiency. The results showed that institutional variables such as RQ and RL have a positive impact on Islamic banking efficiency.

Cooray (2011) explained that the existence of good institutions and legal systems not only strengthens the financial market, but also makes the financial system more efficient through the protection of property rights. In a study entitled "The role of the government in financial sector development," 71 countries were surveyed to examine the impact of institutional quality on financial sector dimensions, size and efficiency ratios from 1990 to 2005 . The results of both studies show that the elements of institutional control have a positive impact on efficiency; thus, concurring with the public interest view.

Hypothesis 3: Institutional control is positively related to bank efficiency. 


\section{METHODOLOGY}

\subsection{Sample of Data}

The data were collected from 16 Islamic banks in Malaysia. The data covers the period 2008 to 2013 and examines the impact of the global financial crisis during this period. A further explanation of the above data follows in the upcoming sections.

\subsubsection{Bank Technical Efficiency}

The dependent variable (i.e. bank efficiency) is shown as technical efficiency (TE), which describes the extent to which the bank can produce the maximum amount of output with a set of inputs. Chortareas, Girardone, and Ventouri (2012) clarified that efficiency is the ability of a firm to fully exploit the available production technology; furthermore, it relates to efficiencies by superior management or technologies. The level of efficiency is gained using a non-parametric approach known as DEA. In this study, we suggest two inputs and two outputs due to the fact that the activities of Islamic banks vary with conventional banks. The inputs are divided into two: total deposits (DEPO) and personnel expenses (PERS) as labour input. For outputs, we use total financing (FIN) and total investment plus securities (INVSET).

\subsubsection{Regulation Indicators}

The data for these variables were obtained from the World Bank's Regulation and Supervision Survey (BRSS). These variables indicate whether bank activities in (a) securities sponsorship, brokerage and securities dealings, and all aspects of the mutual fund industry, (b) securities sponsorship and sale of insurance, (c) real estate investment, development and management are (1) not restricted, (2) a permitted activity, (3) restricted activity, or (4) a prohibited activity. Therefore, the aggregate indicators range from four to sixteen, with higher values indicating greater activity constraints.

\subsubsection{Institutional Variables}

The set of data for institutional variables was obtained from the Worldwide Governance Indicators project, which was established by Kaufmann et al. (2010). These indicators show an aggregate and individual governance indicator for 215 economies over the period 1996 to 2013. This data contains six dimensions of governance, which are (i) voice and accountability, (ii) political stability and absence of violence, (iii) government effectiveness, (iv) regulatory quality, (v) rule of law, and (vi) control of corruption. From these groups of variables, we chose only two indicators as proxies for contract enforcement, namely regulatory quality $(R Q)$ and rule of law (RL).

To perform the calculation, we follow the previous study by Levine (1998) where the rule of law was suggested as an element of enforcement. Rule of law refers to the index outlining how agents rely on the rules of the society and respect them. At the same time, rule of law reflects the quality of execution of 
contracts, property rights, the police, and the courts, as well as the probability of crime and violence. For the rule of law, contract enforcement constitutes one of the pillars, whereas regulatory quality also denotes one contract enforcement proxy. Regulatory quality is complex; however, it is a more effective regulation, which delivers a focus on quality that goes beyond efficiency. High-quality regulation equates to a high level of regulation, which promotes factors such as proportionate, targeted, efficiency, accessibility, and transparency.

\subsubsection{Maqasid Shariah}

In order to measure the impact of Islamic law on bank efficiency, the maqasid shariah index (MSI) will be established. The index, which is adopted from Mohammed et al. (2008), ${ }^{1}$ will cover three objectives: education, justice and public interest (maslahah). The data were gathered from the financial statements of banks. The overall performance indicators for the three shariah objectives for each bank are used to create an individual index. In other words, the MSI for the individual bank is the sum of its performance indicators, which will help with meeting the objectives.

In order to measure the impact of Islamic law on bank efficiency, the MSI is established. These indexes are designed and based on Mohammed et al. (2008). The three elements used for measurement are education, establishing justice and public interest (maslahah). The data were gathered from the financial statements contained in the banks' annual reports. For these indexes, we try to propose Maqasid shariah indexes as suggested by Mustafa et al. (2008). Hence, we try to determine the performance ratio for each of the variables as stated in Table 2. The performance ratios are defined from the annual reports of Islamic banks. The total overall performance indicators for the three Shariah objectives for each bank create an individual MSI. In other words, the MSI for an individual bank is the sum of its performance indicators in order to meet Objective 1 and Objective 3.

As proposed by Mustafa et al. (2008), the evaluation of the individual Islamic bank objectives can be realised as the equation below. For example, the Performance Indicator for Objective 1 is obtained by $\mathrm{PI}(\mathrm{OI})$ :

$$
\begin{aligned}
& W_{1}^{1} \times J_{1}^{1} \times Q_{1}^{1}+W_{1}^{1} \times J_{1}^{2} \times Q_{1}^{2}+W_{1}^{1} \times J_{1}^{3} \times Q_{1}^{3} \\
\mathrm{PI}(\mathrm{OI})= & +W_{1}^{1} \times J_{1}^{3} \times Q_{1}^{3}+W_{1}^{1} \times J_{1}^{4} \times Q_{1}^{4} @ \\
& W_{1}^{1}\left(J_{1}^{1} \times Q_{1}^{1}+J_{1}^{2} \times Q_{1}^{2}+J_{1}^{3} \times Q_{1}^{3}+J_{1}^{4} \times Q_{1}^{4}\right)
\end{aligned}
$$

\footnotetext{
Refers to Mohammed et al. (2015). These indexes are developed from the theory of the objectives of al shariah (maqasid shariah). Maqasid's scholar, Ibn Ashur, mentions that the specific objectives of shariah should include the preservation of order, promotion of human welfare, prevention of corruption, establishment of justice, and maintaining stability and harmony. In addition, Ilal al-Fasi includes objectives such as reforming the human mind, developing the earth, managing benefits for all, preserving order and the system of livelihood, establishing justice, and utilising Allah's natural resources (Ibid). Meanwhile, as suggested by Abu Zaharah (1997), the author has categorised three types called: (1) Tahdhib al-Fard (educating the individual), (2) Iqamah al-Adl (establishing justice), and (3) Jalb al-Maslahah (promoting welfare).
} 
Where,

(O1) denotes the first Shariah objective, i.e. Tahdhib al-Fard (education)

$W_{1}^{1}$ is the weight assigned to the first Shariah objective (derived from Table 2)

$J_{1}^{1}$ denotes the weight assigned to the first element of the first objective (see Table 2)

$J_{1}^{2}$ denotes the weight assigned to the second element of the first objective (see Table 2)

$J_{1}^{3}$ denotes the weight assigned to the third element of the first objective (see Table 2)

$J_{1}^{4}$ denotes the weight assigned to the fourth element of the first objective (see Table 2)

$Q_{1}^{1}$ denotes the evaluations for the performance ratio corresponding to the first element of the first objective

$Q_{1}^{2}$ denotes the evaluations for the performance ratio corresponding to the second element of the first objective

$Q_{1}^{3}$ denotes the evaluations for the performance ratio corresponding to the third element of the first objective

$Q_{1}^{4}$ denotes the evaluations for the performance ratio corresponding to the fourth element of the first objective

Furthermore, the equation $\mathrm{PI}(\mathrm{O} 3)=\mathrm{PI} 13+\mathrm{PI} 23+\mathrm{PI} 33$

Where:

$\mathrm{PI}(\mathrm{O} 3)=W_{3}^{3} \times J_{3}^{1} \times Q_{3}^{1}+W_{3}^{3} \times J_{3}^{2} \times Q_{3}^{2}+W_{3}^{3} \times J_{3}^{3} \times Q_{3}^{3}$

To obtain the Maqasid Index (MSI):

$\mathrm{MSI}=\mathrm{PI}(\mathrm{O} 1)+\mathrm{PI}(\mathrm{O} 3)$

In other words, the Maqasid Index (MSI) for the individual bank is the sum of its performance indicators in respect of Objective 1 and Objective 3 as proposed in our model.

Table 1.

Operationalising objectives of Islamic banking

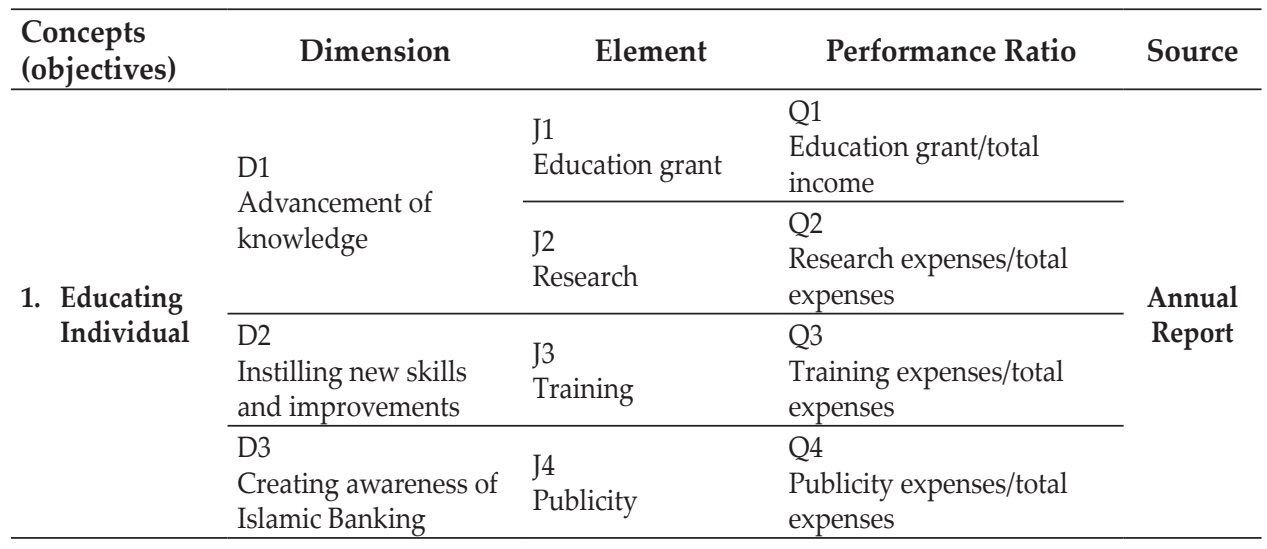


Table 1.

Operationalising objectives of Islamic banking (Continued)

\begin{tabular}{|c|c|c|c|c|}
\hline $\begin{array}{l}\text { Concepts } \\
\text { (objectives) }\end{array}$ & Dimension & Element & Performance Ratio & Source \\
\hline \multirow{3}{*}{$\begin{array}{l}\text { 2. Public } \\
\text { interest }\end{array}$} & $\begin{array}{l}\text { D7 } \\
\text { Profitability }\end{array}$ & $\begin{array}{l}\text { J8 } \\
\text { Profit ration }\end{array}$ & $\begin{array}{l}\text { Q8 } \\
\text { Net profit/total asset }\end{array}$ & \multirow{3}{*}{$\begin{array}{l}\text { Annual } \\
\text { Report }\end{array}$} \\
\hline & $\begin{array}{l}\text { D8 } \\
\text { Redistribution of } \\
\text { income and wealth }\end{array}$ & $\begin{array}{l}\text { J9 } \\
\text { Personal income }\end{array}$ & $\begin{array}{l}\text { Q9 } \\
\text { Zakah/net income }\end{array}$ & \\
\hline & $\begin{array}{l}\text { D9 } \\
\text { Investment in vital real } \\
\text { sector }\end{array}$ & $\begin{array}{l}\text { J10 } \\
\text { Investment ratios in } \\
\text { real sector }\end{array}$ & $\begin{array}{l}\text { Q10 } \\
\text { Investment deposit/total } \\
\text { deposit }\end{array}$ & \\
\hline
\end{tabular}

Source: Mohammed et al. (2008)

Table 2.

Average weights for the three objectives and ten elements given by Shari'ah experts

\begin{tabular}{lclc}
\hline Objectives & $\begin{array}{c}\text { Average weight } \\
\text { (out of 100\%) }\end{array}$ & \multicolumn{1}{c}{ Elements } & $\begin{array}{c}\text { Average } \\
\text { weight } \\
\text { (out of 100\%) }\end{array}$ \\
\hline & & J1. Education grants/donation & 24 \\
1. Education & & J2. Research & 27 \\
(Tahdhib al-Fard) & 30 & J3. Training & 26 \\
& & J4. Publicity & 23 \\
& & Total & 100 \\
\hline 2. 03. Welfare & \multirow{2}{*}{29} & J8. Bank's profit Ratio & 33 \\
(Al-Maslahah) & & J9. Personal income transfers & 37 \\
\hline Total & 100 & J10. Investment ratios in real sector & 30 \\
\hline
\end{tabular}

Source: Mohammed et al. (2008)

\subsubsection{Control Variables}

Sufian and Hassan (2011) demonstrated that economic freedom is important in explaining the performance of banks. We also use the index of economic freedom collected from the database published by the Heritage Foundation, which gives a ranking for every nation on ten broad criteria based on the statistics of the World Bank, the IMF and the Economist Intelligence Unit. These criteria evaluate the success of economics over 185 countries around the world. For the scores, ten arithmetic averages are calculated for the overall score (Index of Economic Freedom) but only four indicators are selected, namely business freedom (BF), monetary freedom (MF), investment freedom (IF) and financial freedom (FF).

In addition, we bring together the rate of GDP to capture the size of an economy. This is also estimated to understand the impact on stemming bank efficiency, as demand for financial products depends on the level of economic activity. Empirical studies are likely to show that countries with relatively high GDP also have efficient banking institutions (Barth et al., 2013; Řepková, 2015; Sufian, 2009). 


\subsubsection{Bank Characteristics}

The bank characteristic variables used in this study include assets (TA), total deposit (TD), asset quality (AQ) and bank liquidity (BL). The bank size variable, which is defined as the natural logarithm of an Islamic bank's total assets, is included in the regression to measure how bank size influences efficiency level. Bank size is also a factor that influences efficiency levels because large banks are able to hold less capital compared to smaller banks, and may also have a greater portfolio and loan diversification and benefit from their size advantages (Barth et al., 2013; Chortareas et al., 2010; Hughes et al., 2008; Sassi, 2013).

We also include equity per total assets (ETA) to use as a proxy for the capital adequacy of banks. For this variable, as stated in Sufian (2009), we have a confident expectation on the sign of variables. Total financing per total assets (FINTA) is included in the model as an indicator of bank liquidity. This variable is predicted to have a positive impact with respect to efficiency (Sassi, 2013; Sufian, 2009).

\subsection{Model Development and Method}

Generally, the estimation model is adapted from the method proposed by Barth et al. (2013) and Chortareas et al. (2012). Barth et al. (2013) worked on the study "Do bank regulation, supervision and monitoring enhance or impede bank efficiency?" while Chortareas et al. (2012) attempted to analyse the dynamic effects of bank regulation or supervision and efficiency by using the DEA method. However, the framework in this study is based on the theory of regulation or supervision applied to the development of the banking industry as described by Barth et al. (2008), Chortareas et al. (2012), and Barth et al. (2013).

Therefore, the aim of this study is to examine the level of banking efficiency and analyse variables such as the characteristics of Islamic banking (total assets, total capital adequacy and cash flows), Maqasid Syariah index, regulation (activity restriction), institutional controls and economic freedom variables in influencing the level of technical efficiency of banking, particularly Islamic banking.

In addition, the estimation model is constructed through different stages. First, the DEA model is used to obtain the level of efficiency, and second, the panel data analysis is completed in order to assess the determinants of Islamic banks' efficiency.

\subsubsection{Bank Efficiency Measurement}

In measuring the technical efficiency scores, the study will adopt the model developed by Barth et al. (2013), Alam (2013), Sassi (2013), and Chortareas et al. (2012). The model has the following characteristics - the DEA technique generates a frontier set by efficient banks and compares it with inefficient banks to produce the core of efficiency.

Moreover, in this study, we propose two inputs and two outputs due to the fact that the structures of financial statements within Islamic banks vary from those in conventional banks. The inputs are divided into two: $\mathrm{X} 1$ : total deposits and X2: personnel expenses as labour input. Thereafter, for outputs: Y1: total financing and Y2: total investment and securities. 
Table 3.

The Technical Efficiency of Islamic Banks in Malaysia

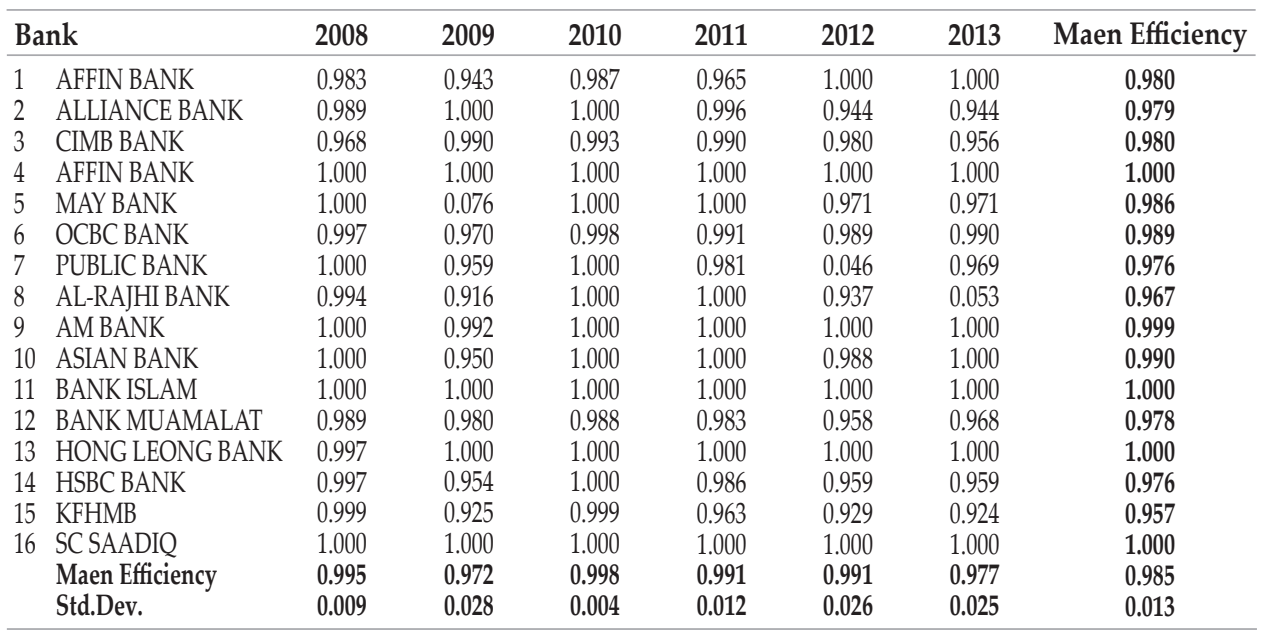

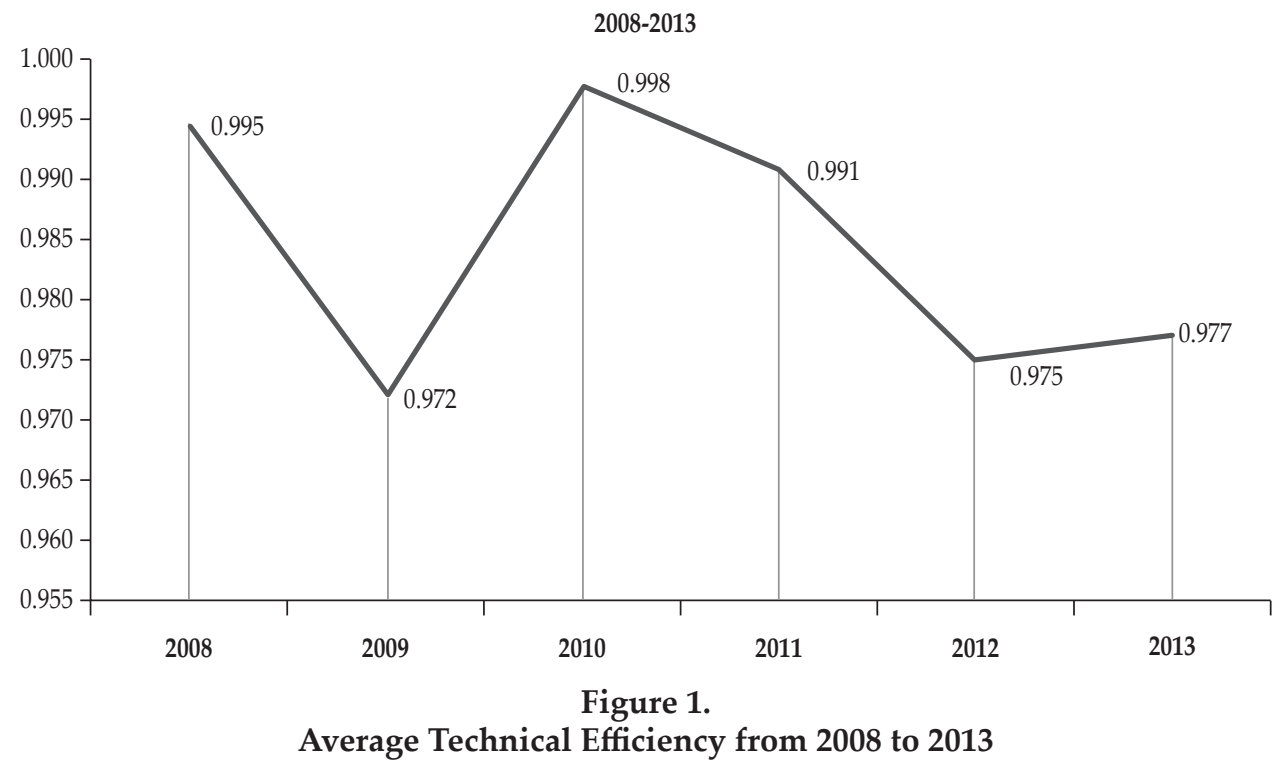

Table 3 outlines the results of the efficiency measurement levels based on the VRS model for ten domestic Islamic banks and six foreign banks. The results in Table 3 explain that the average level of efficiency of Islamic banking is $98.5 \%$, with the minimum level of $97.2 \%$ in 2009 and the maximum level in 2010 with $99.8 \%$. During the study period, it was found that Maybank, Bank Islam Malaysia Berhad, Hong Leong Bank Berhad, and SC Saadiq achieved a 100\% technical efficiency level. Meanwhile, the six lowest-ranking technical efficiency banks were Kuwait Finance House Malaysian Berhad (KFHMB) (95.7\%), Al-Rajhi Bank (96.7\%), HSBC (97.6\%), RHB (97.6\%), Bank Muamalat (97.8\%), and Alliance bank (97.9\%). From 
the observations made of KFHMB, the level of technical efficiency during the study period fluctuated in the first three years and then decreased in the last three years. The lowest technical efficiency values achieved were $92.4 \%$ in 2013 and $99.9 \%$ in 2008 and 2010.

Referring to the analysis of technical efficiency, observations from both domestic and foreign ownership points out that the technical efficiency of both institutions are quite different. Most of the foreign Islamic banks came within the category of lowest technical efficiency; however, SC Saadiq was different, having achieved $100 \%$ technical efficiency.

In contrast to domestic Islamic banking, RHB had a low mean efficiency of $97.6 \%$ compared to a $98.5 \%$ overall mean efficiency. In addition, what is interesting to note is that most of the domestic Islamic banking institutions have a higher level of mean efficiency than the overall mean. However, when it comes to foreign Islamic banks, most fell below the overall mean efficiency. These results are in line with previous studies such as Berger et al. (2000), who concluded that domestic financial institutions are relatively more efficient than foreign institutions.

Additionally, the unfamiliarness hypothesis, as described by Berger et al. (2000), states that foreign banks, which have branch offices located far away, find it more difficult to operate due to differences in their market environment, language, culture and supervisory and monitoring structures.

\subsubsection{Panel Data Approach}

In the second stages, the technical efficiency scores were regressed to find the impact between a set of bank characteristics, regulation, institutional variables, economic freedom, macroeconomic variables and Maqasid Shariah indexes using panel data analysis. Specifically, the model was formally adapted from the approaches suggested by Barth et. al (2013) and Chortareas et al. (2012), which can be written as follows:

$$
T E_{i, t}=\beta_{0}+\beta_{1} S_{i, t}+\beta_{2} P_{i, t}+\beta_{3} K_{i, t}+\beta_{4} M_{i, t}+\beta_{5} E_{i, t}+\beta_{6} V_{i, t}+\varepsilon_{i, t}
$$

TE represents the technical efficiency score of the Islamic bank and $S$ is a vector of Islamic bank characteristics, $\mathrm{P}$ is a regulation indicator, $\mathrm{K}$ is a set of institutional variables, $\mathrm{M}$ is the Maqasid shariah index, $\mathrm{E}$ is a set of economic freedoms, and finally, $\mathrm{V}$ is a macro variable of Islamic bank. More precisely, model equation (5) is described as follows:

$$
\begin{aligned}
& T E_{i, t}=\beta_{0 i}+\beta_{1} A S E T_{i, t}+\beta_{2} F T A_{i, t}+\beta_{3} E T A_{i, t}+\beta_{4} M S I_{i, t}+\beta_{5} A R C_{i, t}+\beta_{6} R Q_{i, t}+\beta_{7} R L_{i, t}+ \\
& \beta_{8} L N K D N K_{i, t}+\beta_{9} E F_{i, t}+u_{i t}
\end{aligned}
$$

As stated previously, in this study we include the MSI because we want to assess its importance in influencing the level of efficiency of Islamic banking. Therefore, the result from this model will explain the commitment of Islamic banking in conducting transactions and banking operations based on actual 
Islamic principles as supported by Ghifari et al. (2015), Sudrajat and Sodiq (2016), and Prasetyowati and Handoko (2016).

Meanwhile, to avoid multicollinearity to the study, separate regression methods were implemented for each of the variables used, such as the studies by Sufian and Habibullah (2014), Boutin-Dufresne et al. (2013), and Sassi (2013). Separate regression methods also aimed to examine the effects of specific bank characteristics on environmental factors while maintaining the bank characteristics variable for each regression model (Triki et al., 2017). Therefore, these separate regression methods are created using different dependent variables, while maintaining the effect of bank characteristics in each of the formed equations (4), (5), (6), and (7) (Sassi, 2013). Equation (8) divides the institutional control variables separately in an attempt to measure the impact of individual variables on the technical efficiency of Islamic banking. In addition, this study uses the 'truncated estimator with bootstrap' value to obtain accurate results such as in the study by Chortareas et al. (2012). Subsequently, to ensure the robustness of the study model, robustness tests were conducted. The model equation in the analysis is as follows:

$$
\begin{aligned}
& T E_{i, t}=\beta_{0}+\beta_{1} A S E T_{i, t}+\beta_{2} F T A_{i, t}+\beta_{3} E T A_{i, t}+\beta_{4} M S I_{i, t}+\beta_{7} L N K D N K_{i, t}+u_{i, t} \\
& T E_{i, t}=\beta_{0}+\beta_{1} A S E T_{i, t}+\beta_{2} F T A_{i, t}+\beta_{3} E T A_{i, t}+\beta_{4} M S I_{i, t}+\beta_{5} A R C_{i, t}+u_{i, t} \\
& T E_{i, t}=\beta_{0}+\beta_{1} A S E T_{i, t}+\beta_{2} F T A_{i, t}+\beta_{3} E T A_{i, t}+\beta_{4} M S I_{i, t}+\beta_{6} R Q_{i, t}+\beta_{7} R L_{i, t}+u_{i t}
\end{aligned}
$$

\section{RESULTS AND ANALYSIS}

This section presents the regression results from the estimation models developed in Chapter 3. In this study, we employ panel data estimation to examine the impact on Islamic bank efficiency.

\subsection{Bank Efficiency and Bank Characteristics}

In this section, we analyse how bank characteristics influence the level of Islamic bank efficiency. The results of the regressions are reported in Table 4. Our results indicate that the first notable result evidences a positive and insignificant relationship between TA and bank efficiency.

On the other hand, the FINTA is positively significant in explaining bank efficiency, which shows that Islamic banks with higher financing-to-asset ratios tend to have higher efficiency scores. While the ETA shows that there is a positive and statistically significant relationship with bank efficiency. This outcome is also supported by Sufian (2009) and Akhigbe and McNulty (2005). This result proves that efficient banks are going to have to deal with more leverage (less equity) compared to less efficient banks, which tend to be more involved in riskier projects. 
Table 4.

Bank Efficiency, Bank Characteristics and GDP

\begin{tabular}{|c|c|c|c|c|}
\hline Variables & $\begin{array}{l}\text { Panel OLS } \\
\text { (Bootstrap) }\end{array}$ & $\begin{array}{c}\text { Random } \\
\text { Effect }\end{array}$ & Fixed Effect & $\begin{array}{l}\text { OLS with Hetero \& } \\
\text { Serial Correlation }\end{array}$ \\
\hline Constant & $2.3109^{* *}$ & $2.3443^{*}$ & $2.2464^{* *}$ & $2.3443^{*}$ \\
\hline $\mathrm{TA}$ & 0.0021 & 0.0020 & -0.0004 & 0.0020 \\
\hline FINTA & 0.0006 & $0.0007^{* *}$ & $0.0009^{* *}$ & $0.0007^{*}$ \\
\hline ETA & 0.0281 & 0.0242 & 0.0135 & $0.0242^{* * *}$ \\
\hline MSI & $0.0028^{*}$ & $0.0028^{* * *}$ & 0.0008 & $0.0028^{*}$ \\
\hline GDP & -0.0507 & $-0.0518^{* * *}$ & -0.0461 & $-0.0518^{* *}$ \\
\hline Diagnostic tests & & & & \\
\hline R-square & 0.1299 & 0.1918 & 0.0138 & 0.1918 \\
\hline Breusch-Pagan LM test & & & & \\
\hline Hausman test & \multicolumn{3}{|c|}{0.9729} & \\
\hline Wooldridge test AR(1) & \multicolumn{4}{|c|}{$10.454^{* *}$} \\
\hline Heteroscedasticity test & \multicolumn{4}{|c|}{$53.2114^{*}$} \\
\hline Number of observations (N) & 96 & 96 & 96 & 96 \\
\hline
\end{tabular}

Note: ${ }^{*}{ }^{* *}$ and ${ }^{* * *}$ - significant at the $1 \%, 5 \%$ and $10 \%$ levels; t-values in parentheses

As expected, we find that the MSI is positively significant with bank efficiency. This finding shows that, with a better performance, it will increase the level of bank efficiency. According to Antonio et al. (2012), the maqasid index approach is a prerequisite for the development of Islamic banking because it serves as a benchmark for Islamic banking performance levels that are more conceptualised on Shariah goals and objectives. Therefore, this result will show that the performance of Islamic banking contributes to increased technical efficiency. This statement is supported by Ftiti et al. (2013), who stated that the monitoring and regulation of Islamic banks under Shariah guidelines can make banking operations more efficient and stronger, especially during an economic crisis.

As far as the macro environment is concerned, we find some interesting relationships. The result suggests a negative and significant relationship between GDP and bank efficiency. This result is similar to the study conducted by Sufian (2016) in which this negative relationship confirms that high economic growth will provide a good economic environment and reduce the barriers of entry to banking institutions into the market. This will indirectly increase competition in the banking sector, and consequently, reduce profitability (Liu \& Wilson, 2011).

\subsection{Bank Efficiency and Bank Regulation}

From Table 5, which focuses on the activity restriction (ARC), our results show a positive and statistically significant relationship with bank efficiency. To recall, higher values for ARC imply greater restrictions on the activities of Islamic banks. The result of a positive and statistically significant relationship indicates that restricting banks from engaging in activities is strongly associated with greater bank efficiency. This result implies that the activities of Islamic banks are regulated in accordance to Shariah law and that all the operations and businesses 
must follow rules that align with Islamic law, in which all unlawful activities are prohibited.

Table 5.

Bank Efficiency and Bank Regulation

\begin{tabular}{|c|c|c|c|c|}
\hline Variables & $\begin{array}{l}\text { Panel OLS } \\
\text { (Bootstrap) }\end{array}$ & $\begin{array}{c}\text { Random } \\
\text { Effect }\end{array}$ & Fixed Effect & $\begin{array}{c}\text { OLS with } \\
\text { Hetero \& Serial } \\
\text { Correlation }\end{array}$ \\
\hline Constant & $0.7894^{*}$ & $0.7916^{*}$ & $0.8531^{* *}$ & $0.7916^{*}$ \\
\hline $\mathrm{TA}$ & 0.0021 & 0.0020 & -0.00004 & 0.0020 \\
\hline FINTA & 0.0005 & $0.0007^{* *}$ & $0.0009^{* *}$ & $0.0007^{*}$ \\
\hline ETA & 0.0288 & 0.0251 & 0.0158 & $0.0251^{* * *}$ \\
\hline MSI & $0.0028^{*}$ & $0.0027^{* * *}$ & 0.0003 & $0.0027^{*}$ \\
\hline Bank regulation & & & & \\
\hline $\mathrm{ARC}$ & $0.0178^{* * *}$ & $0.0180^{* *}$ & 0.0167 & $0.0180^{* *}$ \\
\hline Diagnostic tests & & & & \\
\hline R-square & 0.1361 & 0.1937 & 0.0041 & 0.1937 \\
\hline Breuch-Pagan LM test & & & & \\
\hline Hausman test & \multicolumn{4}{|c|}{0.9710} \\
\hline Wooldridge test AR(1) & \multicolumn{4}{|c|}{2.698} \\
\hline Heteroscedasticity test & \multicolumn{4}{|c|}{$71.40476^{*}$} \\
\hline Number of observations (N) & 96 & 96 & 96 & 96 \\
\hline
\end{tabular}

Note: ${ }^{*}, * *$ and ${ }^{* * *}$ - significant at the $1 \%, 5 \%$ and $10 \%$ levels; t-values in parentheses

This result is similar to the previous studies by Barth et al. (2013), Chortareas et al. (2012), and Agoraki et al. (2011) who stated that the restriction of activity in banking institutions will increase efficiency. Based on the 'public interest view' hypothesis, the restriction of activity would reduce 'moral hazard' problems; banks will take risks, which will prevent them from becoming too large and complex. This process will involve monitoring. As a result, the level of banking efficiency can be increased.

\subsection{Bank Efficiency and Institutional Variables}

Table 6 outlines the result of the relationship between the proxies of contract enforcement and efficiency. The result shows that there is a negative and insignificant relationship between rule of law (RL) and efficiency. Regulatory quality $(R Q)$ revealed that $R Q$ has a positively significant relationship with efficiency. 
Table 6.

Bank Efficiency and Institutional Variables

\begin{tabular}{lcccc}
\hline Variables & $\begin{array}{c}\text { Panel OLS } \\
\text { (Bootstrap) }\end{array}$ & $\begin{array}{c}\text { Random } \\
\text { Effect }\end{array}$ & Fixed Effect & $\begin{array}{c}\text { OLS with } \\
\text { Hetero \& Serial } \\
\text { Correlation }\end{array}$ \\
\hline Constant & $1.0004^{*}$ & $1.0850^{*}$ & $1.5459^{*}$ & $1.0850^{*}$ \\
TA & -0.00008 & -0.0038 & $-0.0240^{* *}$ & -0.0038 \\
FINTA & 0.0004 & 0.0006 & $0.0008^{* *}$ & $0.0006^{* *}$ \\
ETA & 0.0144 & -0.0030 & $-0.0722^{* * *}$ & -0.0030 \\
MSI & $0.0030^{*}$ & $0.0031^{* *}$ & 0.0011 & $0.0031^{* *}$ \\
Contract Enforcement & & & & \\
RQ & 0.0302 & $0.0356^{* * *}$ & $0.0659^{* *}$ & $0.0356^{* * *}$ \\
RL & -0.0722 & -0.0712 & -0.0693 & -0.0712 \\
Diagnostic tests & & & & 0.1148 \\
R-square & 0.1180 & 0.1148 & 0.0273 & \\
Breuch-Pagan LM test & & & & \\
Hausman test & $7.34^{* *}$ & & 9.51 & \\
Wooldridge test AR(1) & & & $6.081^{* *}$ & \\
Heteroscedasticity test & & & $95.6084^{*}$ & \\
Number of observations (N) & 96 & 96 & 96 & 96 \\
\hline
\end{tabular}

Note: ${ }^{*}{ }^{* *}$ and ${ }^{* * *}$ - significant at the $1 \%, 5 \%$ and $10 \%$ levels; t-values in parenthesis

As proposed in the Worldwide Governance Indicators, it is apparent that the concept of regulatory quality can capture perceptions surrounding the ability of the government to formulate and implement sound policies and regulations that permit and promote Islamic bank development. The results indicate that, if regulation is implemented, it can increase the level of efficiency within the Islamic banking industry. This proves that policy and laws created under Shariah laws are suitable for a business environment like Malaysia. This belief is supported by Radaelli and Francesco (2007), who stated that when good-quality regulation is implemented, it will enhance economic growth and lead to better governance.

\subsection{Bank Efficiency and Economic Freedom}

The results from Table 7 report a significant and negative relationship between $\mathrm{BF}$ and bank efficiency. The negative coefficient of the business freedom variable indicates that Islamic banks have a greater ability to enter the banking industry and obtain an easy licence, create products and services, and close the business. All will dampen bank efficiency. 
Table 7.

Bank Efficiency and Economic Freedom

\begin{tabular}{|c|c|c|c|c|}
\hline Variables & $\begin{array}{l}\text { Panel OLS } \\
\text { (Bootstrap) }\end{array}$ & $\begin{array}{c}\text { Random } \\
\text { Effect }\end{array}$ & Fixed Effect & $\begin{array}{l}\text { OLS with } \\
\text { Hetero \& Serial } \\
\text { Correlation }\end{array}$ \\
\hline Constant & $1.5348^{*}$ & $1.5324^{*}$ & $1.4761^{*}$ & $1.5324^{*}$ \\
\hline $\mathrm{TA}$ & 0.0025 & 0.0032 & 0.0065 & 0.0032 \\
\hline FINTA & 0.0007 & $0.0010^{* *}$ & $0.0011^{* *}$ & $0.0010^{*}$ \\
\hline ETA & 0.0219 & 0.0159 & 0.0222 & 0.0159 \\
\hline MSI & $0.0028^{*}$ & $0.0027^{* * *}$ & 0.0020 & $0.0027^{*}$ \\
\hline $\mathrm{BF}_{\mathrm{t}}$ & $-0.0026^{*}$ & $-0.0027^{*}$ & $-0.0028^{*}$ & $-0.0027^{*}$ \\
\hline MF & $-0.0071^{* * *}$ & $-0.0072^{* *}$ & $-0.0072^{* *}$ & $-0.0072^{* *}$ \\
\hline IF & 0.0017 & $0.0018^{* *}$ & $0.0018^{* *}$ & $0.0018^{* *}$ \\
\hline FF & $0.0014^{* *}$ & $0.0014^{* *}$ & $0.0013^{* *}$ & $0.0013^{* *}$ \\
\hline Diagnostic tests & & & & \\
\hline R-square & 0.3156 & 0.1642 & 0.1225 & 0.1642 \\
\hline Breusch-Pagan LM test & & & & \\
\hline Hausman test & \multicolumn{4}{|c|}{1.32} \\
\hline Wooldridge test AR(1) & \multicolumn{4}{|c|}{1.365} \\
\hline Heteroscedasticity test & \multicolumn{4}{|c|}{$70.1630^{*}$} \\
\hline Number of observations (N) & 96 & 96 & 96 & 96 \\
\hline
\end{tabular}

Note: ${ }^{*}{ }^{* *}$ and ${ }^{* * *}$ - significant at the $1 \%, 5 \%$ and $10 \%$ levels; $t$-values in parenthesis

Therefore, for Islamic banks to operate efficiently, there should be free entry; hence, more Islamic banks will exist in the market. This will create a situation where Islamic banks will compete among each other and indirectly reduce efficiency levels (Sufian \& Habibullah, 2014). The MF variable also shows a significant and negative relationship with bank efficiency. It indicates that less government intervention through monetary policy will hinder the level of bank efficiency. However, in the context of Malaysia's emerging economy, price stability without intervention is ideal for the free market. However, government intervention can reduce excessive price hikes through price control. The negative relationship exhibited by MF also supports the existence of government intervention in the economy. Indeed, it also aids in establishing the importance of price and exchange rate controls to ensure the stability and growth performance of the banking sector in Malaysia, in particular Islamic banking (Sufian \& Habibullah, 2014).

Thereafter, financial freedom (FINF) reveals that there is a positive and statistical significance when it comes to bank efficiency. This indicates that less government control over financial activities will lead to Islamic banks becoming more efficient. This result suggests that financial freedom will enhance technical efficiency, as supported by Sufian and Zulkhibri (2015). According to Sufian and Zulkhibri (2015), the conclusion to be drawn from this positive relationship is that banking profitability and efficiency will increase if there is an element of banking security and freedom of government control over the activities of the sector. This is because government intervention or control will prevent the institution from 
engaging in important financial activities, which in turn can reduce competition between institutions, while reducing the technical efficiency of banking.

For investment freedom (INVF), there is a statistically significant and positive impact on bank efficiency. This explains how high investment freedom contributes to technical efficiency. Gasaymeh et al. (2013) described investment freedom as a free and open investment environment where more entrepreneurial opportunities and incentives are provided to expand economic activities, increase productivity and provide employment opportunities; thus, enhancing the efficiency of the Islamic banking sector.

\section{CONCLUSION AND RECOMMENDATION}

This study has examined how the rules of the bank and the Maqasid Shariah index affect bank efficiency by considering 16 Islamic banks in Malaysia from 2008 to 2013. The results of the four models show that the MSI has a positive and significant relationship with technical efficiency. This result supports the 'public interest' view, which explains that the government acts as an agent to protect the public interest through the regulatory process of banking activities, which indirectly raises banks' efficiency and then resolves the problem of market failure. The situation also proves that a positively performing Islamic bank that conducts activities in line with Maqasid Shariah will contribute to a high level of efficiency.

Furthermore, the results of activity restriction (ARC) also indicate that there is a significant positive relationship with technical efficiency. This result is similar to the studies of Alam (2013) and Pasiouras et al. (2009), who outlined that restrictions on banking activities would increase the level of efficiency of Islamic banking. This finding is in accordance with the concept of Islamic banking where every activity or transaction in Islamic banks must be in accordance with the requirements of Maqasid. These results support the hypothesis of public interest in influencing technical efficiency.

Moreover, for institutional variables, the results for the RL variable showed a negative and insignificant relationship with Islamic banking efficiency. In contrast, the $R Q$ variable has a positive and significant relationship with efficiency. These results indirectly support the hypothesis of public interest, which states that changes in RQ will enhance Islamic banking efficiency. Lastly, the results of the economic freedom indexes show that there is a significant relationship with bank efficiency. This explains that government intervention in the market is essential in controlling foreign exchange rates and controls to ensure the stability and performance of the banking sector. Based on the results, it is therefore recommended that the data for the Maqasid Shariah indexes are sufficient; hence, further study should be undertaken with the aim of contributing more significantly to the efficiency of Islamic banks. In addition, this study recommends that future studies should conduct research on the Maqasid Shariah index for individual Islamic banks. 


\section{REFERENCES}

Agoraki, M. E. K., Delis, M. D., \& Pasiouras, F. (2011). Regulations, Competition and Bank Risk-taking in Transition Countries. Journal of Financial Stability, 7, 38-48.

Ahmad Mokhtar, H. S., Abdullah, N., \& Al-Habshi, S. M. (2007). Technical and Cost Efficiency of Islamic Banking in Malaysia. Review of Islamic Economics, 11(1), 5-40.

Ajakaiye, O., \& Tarp, F. (2012). Finance and Economic Development in Africa: Introduction and Overview. Journal of African Economies, 21(suppl 1), i3-i9. doi:10.1093/jae/ejr048

Akhigbe, A., \& McNulty, J. (2005). Profit Efficiency Sources and Differences among Small and Large U.S. Commercial Banks. Journal of Economics and Finance, 29(3), 289-299.

Alam, N. (2013). Impact of Banking Regulation on Risk and Efficiency in Islamic Banking. Journal of Financial Reporting and Accounting, 11(1), 29-50.

Al-Delaimi, K., \& Battall, A. H. (2006). Using Data Envelopment Analysis to Measure Cost Efficiency with An Application on Islamic Banks. Scientific Journal of Administrative Development, 4,134-156.

Al-Jarhi, M. A. (2009). Islamic Finance: An Efficient and Equitable Option. Jeddah, Saudi Arabia: The Islamic Research and Training Institute.

Allen, F., \& Carletti, E. (2013). New Theories to Underpin Financial Reform. Journal of Financial Stability, 9, 242-249.

Antonio, M. S., Sanrego, Y. D., \& Taufiq, M. (2012). An Analysis of Islamic Banking Performance: Maqashid Index Implementation in Indonesia and Jordania. Journal of Islamic Finance, 1(1), 012-029.

Ayadi, R., Arbak, E., Ben-Naceur, S., \& Groen, W. P. De. (2013). Financial Development, Bank Efficiency and Economic Growth Across the Mediterranean. Mediterranean Prospects, 1-17. Retrieved from www.medpro-foresight.eu

Barra, C., Destefanis, S., \& Lavadera, G. L. (2013). Regulation and Crisis: The Efficiency of Italian Cooperative Banks (Working Paper No. 338).

Barth, J. R., Caprio Jr, G., \& Levine, R. (2004). Bank Supervision and Regulation: What Works Best? Journal of Financial Intermediation, 13, 205-248.

Barth, J. R., Caprio Jr, G., \& Levine, R. (2006). Rethinking Bank Regulation: Till Angels Govern. Cambridge, UK: Cambridge University Press.

Barth, J. R., Caprio Jr, G., \& Levine, R. (2008). Bank Regulations Are Changing: For Better or Worse? Comparative Economic Studies, 50, 537-563.

Barth, J. R., Lin, C., Ma, Y., Seade, J., \& Song, F. M. (2013). Do Bank Regulation, Supervision and Monitoring Enhance or Impede Bank Efficiency? Journal of Banking and Finance, 37(8), 2879-2892.

Battese, G. E., \& Coelli, T. J. (1995). A Model for Technical Inefficiency Effects in A Stochastic Frontier Production Function for Panel Data. Empirical Economics, 20, 325-332.

Beck, T., Demirgüç-Kunt, A., \& Merrouche, O. (2012). Islamic vs. Conventional Banking: Business Model, Efficiency and Stability. Journal of Banking E Finance. 37(2), 433-447. doi:10.1016/j.jbankfin.2012.09.016.

Beltratti, A., \& Stulz, R. M. (2009). Why Did Some Banks Perform Better during The Credit Crisis? A Cross-country Study of The Impact of Governance and Regulation. (Working Paper No. 15180). Retrieved from NBER. 
Berger, A. N., \& Humphrey, D. B. (1997). Efficiency of Financial Institutions: International Survey and Directions for Future Research. European Journal of Operational Research, 98(2), 175-212.

Boutin-Dufresne, F., Peña, S., Williams, O., \& Zawisza, T. A. (2013). Benchmarking Banking Sector Efficiency Across Regional Blocks in Sub-Saharan Africa: What Room for Policy? (Working Paper No. WP/13/51, 1-28). Retrieved from IMF.

Canhoto, A., \& Dermine, J. (2003). A Note on Banking Efficiency in Portugal, New vs. Old Banks. Journal of Banking and Finance, 27, 2087-2098.

Chortareas, G., Girardone, C., \& Ventouri, A. (2012). Bank Supervision, Regulation, and Efficiency: Evidence from the European Union. Journal of Financial Stability, 8, 292-302.

Cooray, A. (2011). The Role of The Government in Financial Sector Development. Economic Modelling, 28,(3), 928-938.

Demirguc-Kunt, A., Laeven, L., \& Levine, R. (2004). Regulations, Market Structure, Institutions, and the Cost of Financial Intermediation. Journal of Money, Credit and Banking, 36(3), 593-622.

Forughi, S. H. Z., \& De Zoysa, A. D. (2012). Australian Banks Performance during the Global Financial Crisis: An Analysis on the Efficiency and Productivity. Saarbrucken, Germany: Lambert Academic Publishing.

Fries, S., \& Taci, A. (2004). Cost Efficiency of Banks in Transition: Evidence from 289 Banks in 15 Post-Communist Countries. European Bank for Reconstruction and Development, 86, 1-29.

Ftiti, Z., Nafti, O., \& Sreiri, S. (2013). Efficiency of Islamic Banks. The Journal of Applied Business Research, 29(1), 285-304.

Gasaymeh, A. S., Majid, M. A., Karim, Z. A., \& Jusoh, M. (2013). Economic Freedom, Country Risk and Banking Efficiency: The Case of Potential Gulf Countries Union. Paper Presented at PERKEM, Prosiding PERKEM, VII, JILID, 3, 14551470. ISSN: 2231-962X

Ghifari, M. A., Handoko, L. H., \& Yani, E. A. (2015). Analisis Kinerja Perbankan Syariah di Indonesia dan Malaysia dengan Pendekatan Maqasid Indeks. Jurnal Ekonomi dan Perbankan Syariah, 3(2), 47-66.

Haque, F., \& Brown, K. (2016 ). Bank Ownership, Regulation and Efficiency: Perspectives from the Middle East and North Africa (MENA). International Review of Economics and Finance, 47, 273-293. Retrieved from

http://dx.doi.org/10.1016/j.iref.2016.10.015

Hasan. T., Mohamad, S., \& Bader, M. K. (2009). Efficiency of Conventional versus Islamic Banks: Evidence from the Middle East. International Journal of Islamic and Middle Eastern Finance and Management, 2(1), 46-65.

Hassan, M. and Dridi, J. (2010). The Effects of Global Crisis on Islamic and Conventional Banks: A Comparative Study. (Working Paper No. WP/10/201). Retrieved from IMF.

Hassan, M. K., Sanchez, B., \& Yu, J. S. (2011). Financial Development and Economic Growth: New Evidence from Panel Data. The Quarterly Review of Economics and Finance, 51(1), 88-104. doi:10.1016/j.qref.2010.09.001

Hughes, J. P., \& Mester, L. J. (2008). Efficiency in Banking: Theory, Practice, and Evidence (Working Paper No. 08-1). Retrieved from Federal Reserve Bank of Philadelphia. 
Ibrahim, S. H., Wirman, A., Alrazi, B., Mohamed Nor, M. N., \& Pramono, S. (2004). Alternative Disclosure \& Performance Measures for Islamic Banks. (Working Paper No. ) Retrieved from International Islamic University Malaysia, Department Of Accounting, International Islamic University Malaysia.

Ibrahim, W. H. W., \& Ismail, A. G. (2015) Conventional bank and Islamic banking as institutions: Similarities and differences. Humanomics, 31(3), 272-298.

Ismail, A. G., \& Tohirin, A. (2010) Islamic Law and Finance. Humanomics, 26(3), 178-199.

Ismail, A. G., Mat Zain, M. N., \& Shahimi, S. (2013). Applied Shari'ah in Financial Transactions. Volume II. Germany: LAP LAMBERT Academic Publishing. ISBN-13: 978-3-8484-1833-6.

Jauziyah, I. Q. (1973). I'lamul Muwaqqi'in 'an Rabbil Alamin. Editor: Thaha Abdur Rauf Sa'd. Beirut: Darul Jail .

Jazil, T., \& Syahruddin. (2013). The Performance Measures of Selected Malaysian and Indonesian Islamic Banks based on The Maqasid al- Shariah Approach.

Kamarudin, F., \& Yahya, M. H. (2013). Cost, Revenue and Profit Efficiency in Islamic vs Conventional Banks: Empirical Evidence using Data Envelopment Analysis (DEA). Pertanika Journal Social Science and Humanity, 21(5),1-18.

Kamarudin, F., Sufian, F., \& Nassir, A. M. (2016). Does Country Governance Foster Revenue Efficiency of Islamic and Conventional Banks in GCC Countries? EuroMed Journal of Business, 11(2), 181-211.

Kasman, A., \& Yildirim, C. (2006). Cost and Profit Efficiencies in Transition Banking: The Case of New EU Members. Applied Economics, 38, 1079-1090.

Kaufmann, K., Kraay, A., \& Mastruzzi, M. (2010). Governance Matters V: Worldwide Governance Indicators. (Working Paper No. WPS4012). Retrieved from: The World Bank.

Kuipers, D. R., Miller, D. P., \& Patel, A. (2009). The Legal Environment and Corporate Valuation: Evidence from Cross-border Takeovers. International Review of Economics and Finance, 18(4), 552-567.

Kuppusamy, M., Saleh, A. S., \& Samudhram, A. (2010). Measurement of Islamic Banks Performance using a Shariah Conformity and Profitability Model. Journal Review of Islamic Economics, 13(2), 35-48.

Laeven, L., \& Levine, R. (2009). Bank Governance, Regulation and Risk Taking. Journal of Financial Economics, 93, 259-275

Lensink, R., Meesters, A., \& Naaborg, I. (2008). Bank Efficiency and Foreign Ownership: Do Good Institutions Matter? Journal of Banking and Finance, 32(5), 834-844.

Levine, R. (1998). The Legal Environment, Banks, and Long-Run Economic Growth. Journal of Money, Credit and Banking, 30(3), 596-620.

Liu, H., \& Wilson, J. O. S. (2011). Competition and Risk in Japanese Banking. The European Journal of Finance, 19(1), 1-18. Retrieved from:

papers.ssrn.com/abstract $=1615330$

Mangkuprawira, T. S. (2009). Horison Bisnis, Manajemen, dan Sumber Daya Manusia. 2nd ed. Bogor, Indonesia: IPB Press

Massally, T. K., \& Duff, S. (15 May 2018). What Can We Learn from Sierra Leone's New Regulatory Sandbox? CGAP [Blog post]. Retrieved from: http://www. cgap.org/blog/what-can-we-learn-sierra-leones-new-regulatory-sandbox 
Mohammed, M. O., Razak, D. A., \& Taib, F. M. (2008). The Performance Measures of Islamic Banking based on Maqasid Framework. Kertas dibentang di IIUM International Accounting Conference (INTAC IV), Putrajaya Marriot. Memenangi Kertas terbaik.

Mohammed, M. O., Tarique, K. M., \& Islam, R. (2015). Measuring the Performance of Islamic Banks using Maqasid-based Model. Intellectual Discourse, 23(Special Issue), 401-424.

Monge-Naranjo, A. (2009). Entrepreneurship and Firm Heterogeneity with Limited Enforcement. Annals of Finance, 5(3-4), 465-494.

Murinde, V. (2012). Financial Development and Economic Growth: Global and African Evidence. Journal of African Economies, 21(suppl 1), i10-i56. doi:10.1093/ jae/ejr042

Ngalim, S. M., Ismail, A. G., \& Yaa'kub, N. I. (2015). A Comparative Analysis of the Maqasid Shari'ah of Islamic Banks in Malaysia, Indonesia and the Gulf Cooperation Council Countries. In M. Asutay \& A. Q. Turkistani (Eds.) Islamic Finance, Political Economy, Performance and Risk, Volume I, Berlin \& London: Gerlach Press.

Othman, N., Abdul-Majid, M., \& Rahman, A. A. (2017). Partnership Financing and Bank Efficiency. Pacific-Basin Finance Journal, 46, 1-13.

Pasiouras, F., Tanna, S., \& Zopounidis, C. (2008). Banking Regulations, Cost and Profit Efficiency: Cross-Country Evidence. Retrieved from Electronic Copy: http://ssrn.com/abstract:1103436

Prasetyowati, L. A., \& Handoko, L. H. (2016). Pengukuran Kinerja Bank Umum Syariah dengan Maqasid Index dan Sharia Conformity and Profitability (SCNP). Jurnal Akuntansi dan Kewangan Islam, 4(2), 107-130.

Radaelli, C. M., \& Francesco, F. D. (2007). Regulatory Impact Assessment. In R. Baldwin, M. Core, \& M. Lodge (Eds), The Oxford Handbook of Regulation (pp. 279-301). Oxford, UK: Oxford University Press

Řepková, I. (2015) Banking Efficiency Determinants in The Czech Banking Sector. Procedia Economics and Finance, 23, 191-196.

Reverchuk, S., Lobozynska, S., \& Megits, N. (2013). Evaluating the Efficiency of Banking System during a Pre-crisis and Crisis Period by using Cluster Analysis (2004-2019). SAGE Open, 1-19. doi: 10.1177/2158244013504575

Sassi, H. (2013) The Impact of Bank Regulations and Institutions of Efficiency in selected MENA Banks. International Journal of Economics and Finance, 5(8), 84100.

Sealay, C. W. and Lindley, J. T. (1997). Inputs, Outputs and A Theory of Production and Cost at Depository Financial Institutions. The Journal of Finance, 32(4), 1251-1266.

Sudrajat, A. \& Sodiq, A. (2016). Analisis Penilaian Kinerja Bank Syariah berdasarkan Indeks Maqasid Syariah. Jurnal Bisnis dan Manajemen Islam, 4(1), 178-200.

Sufian, F. (2009) Determinants of Bank Efficiency during Unstable Macroeconomics Environment: Empirical Evidence from Malaysia. Research International Business and Finance, 23, 54-77

Sufian, F. (2016). Determinants of Efficiency in the Malaysian Banking Sector: Evidence from Semi-parametric Data Envelopment Analysis Method. Studies in Microeconomics, 4(2), 1-22. 
Sufian, F., \& Habibullah, M. S. (2014). Freedom and Bank Efficiency: Does Ownership and Origins Matter? Journal of Financial Regulation and Compliance, 22(3), 174-207.

Sufian, F., \& Hassan, M. K. (2011). Economic Freedom and Bank Intermediation Spreads: Do Countries Level of Economics Development make a Difference? Social Science Research Networks, 1-35. Retrieved from: http://dx.doi.org/10.2139/ ssrn. 1931090

Sufian, F., \& Zulkhibri, M. (2015). The Nexus between Economic Freedom and Islamic Bank Profitability in the MENA Banking Sectors. Global Business Review, 16(5s), 58s-81s.

Stivalkova, Z. (2014). Comparison and Evaluation of Bank Efficiency in Selected Countries in EU. Procedia Economics and Finance, 12, 644-653.

Triki, T., Kouki, I., Dhuou, M. B., \& Calice, P. (2017). Bank Regulation and Efficiency: What Works for Africa? Research in International Business and Finance, 39, 183205.

Yilmazkuday, H. (2011). Thresholds in the Finance-Growth Nexus: A Crosscountry Analysis. The World Bank Economic Review, 25(2), 278-295.

Yubi, M. S. (1998). Maqashid asy-Syariah al-Islamiyah Wa 'Alaqatuha Bil Adillah Asy-Syar'iyyah.

Zhang, J., Wang, P., \& Qu, B. (2012). Bank Risk Taking, Efficiency, and Law Enforcement: Evidence from Chinese City Commercial Banks. China Economic Review, 23(2), 284-295. doi:10.1016/j.chieco.2011.12.001 
